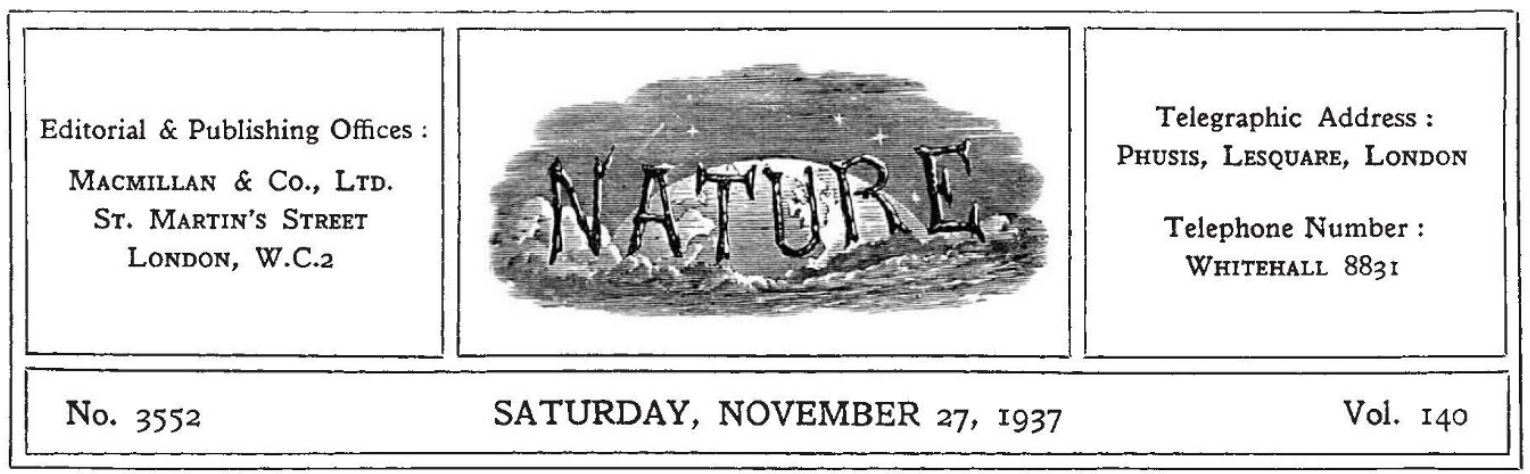

\title{
Defence and Economic Adjustment
}

$\mathrm{T}$ HE recent debate in the House of Commons on the second reading of the Air Raid Precautions Bill brought into clear prominence the close contact between the work of chemists and other men of science and protection from its devastating consequences under the conditions of modern warfare. Mr. G. Lloyd, Under-Secretary of the Home Office, made a comprehensive survey of the measures taken by the Government, and in course of development, to provide the civilian population with whatever means of defence is practicable against effects of air raids. The object of his Department is to make the community as a whole, as well as individual citizens, aware of the dangers of high explosives, toxic gases and incendiary bombs set free from enemy aircraft, and to institute reasonable precautionary measures against them. Possibly some of these anticipated dangers are exaggerated, especially that from gas, but it would be folly to disregard them; but for psychological reasons the people of the country must be given a certain amount of confidence in protective measures in order to prevent them from becoming panic-stricken. Even although it is sometimes difficult to distinguish between the necessity of expenditure upon increased armaments and that of defence programmes, it is in the interest of everyone that whatever precautionary measures are planned or contemplated should be as efficient as science can make them.

The attitude which chemists and other scientific workers should take in regard to the manufacture of munitions of war has been discussed on many occasions, but opinions upon it vary as much among them as they do among citizens in general. The suggestion put before the Technical Committee of the Disarmament Conference that the chemists of the world should include in their code of ethics an undertaking not to work knowingly on the development and production of any prohibited method of warfare, and to expose publicly anyone who was detected in such work, is altogether impracticable. Chemists are citizens as well as men of science, and their services should, therefore, be available for what is regarded as the good of the community. At all stages of human history men have used for purposes of war the most effective means of destruction known to them; and there is little difference in principle in the employment of Greek fire many centuries ago and the use of incendiary bombs to-day. Even in those days boiling oil and molten lead were used as measures of defence against attacks on the walls of eities as well as of fortresses.

The scientific worker cannot stand apart, therefore, from reasonable and practicable steps taken towards the protection of the civil popula. tion from aerial attacks. He, with many others, may deplore the loss of his faith in the progressive ethical development of the human race, but his natural humanity must make him play his part in endeavours to prevent suffering and death.

While, however, we in Great Britain are planning and undertaking a defence programme which will cost many millions of pounds, it should not be forgotten that France, Germany and other nations have instituted similar protective measures against aerial attacks by other nations-ourselves included. As it may be assumed that most people wish to carry on their work in peace and to promote the industry and commerce of their country, such a condition of things is a reproach to human intelligence. It represents the acceptance of a 
policy of despair of avoiding war instead of attempting to discover the causes which lead to armed conflict. Fortunately, efforts are being made in several quarters to promote inquiries into such causes before appeals are made to force. In a petition presented by a deputation to the Prime Minister on November 1, it was urged that H.M. Government should take the initiative in instituting an inquiry into the fundamental causes of rivalry and unrest among nations. More than one hundred fellows of the Royal Society were among the influential signatories of this petition. They, in common with many other distinguished representatives of other fields of intellectual activity, are horrified at the barbaric ways in which progressive scientific knowledge is permitted to be used in operations of war, and associate themselves with any action which may assist in preventing such calamities.

It was suggested by the petitioners that the inquiry might involve the collection and consideration of the basic facts in regard to such questions as access to war materials and world markets, colonial development, problems of surplus populations, and so on, which are often discussed without adequate knowledge and judged without evidence. Though some countries may decline to participate in such an inquiry, or be influenced by the results, it would represent a search for some means of reconciling conflicting national claims and thus make manifest the desire to promote peace on a secure and just foundation. In his speech at the Lord Mayor's banquet on November 9, and again in an address at Edinburgh three days later, the Prime Minister expressed his active interest in efforts of this kind to inquire into the origin and substance of the fears and suspicions which exist among nations, with the view of removing them. "Our country," he said, "has behind her vast, almost illimitable resources, and our very strength makes it easier for us to appeal to others to join in applying our common-sense, our common humanity, to the solution of those problems which carry with them such tremendous possibility for happiness or for misery to the future of the human race. I have faith in human nature. Because I have that faith I believe there will be a ready response to such an appeal."

The economic commission suggested by King Leopold of the Belgians a few months ago would have the same objects as those to which the Prime Minister referred. At the Guildhall on November 17, responding to the toast proposed by the Lord
Mayor of London, King Leopold expressed the hope that Great Britain would take a prominent part in inquiring into the economic difficulties which lie at the root of the international problems which beset the world. "In order to solve those difficulties," he said, "we should need to get a clear view of economic realities seen with a dispassionate eye and divorced from every other consideration. The British Empire represents so important a part of the human race that it cannot help but realize more clearly than any other nation how closely the fate of mankind is bound up with its own. That is why your understanding of the great universal problems is so profound and why it is permissible to be hopeful that Great Britain may play a prominent part in the search for a solution of the major economic difficulties." Questioned upon the subject of this appeal in the House of Commons on Monday, the Prime Minister said that he was glad to have an opportunity of responding cordially to it on behalf of the Government, which, he said, are "fully prepared to play their part in the search for a solution of the world's major economic difficulties"

The Anglo-American trade agreement, which, after months of informal conversations, has now reached a stage at which, as announced by the Prime Minister in the House of Commons on November 18, definite steps can be taken towards actual negotiation of terms, is an example of what can be done by the joint discussion of national problems; and its political implications are as important as its economic interests. It is by the application of scientific methods and of the scientific spirit in these fields that there is hope of discovering the causes, and averting the consequences, of international disputes. Though the impartial and responsible study of some of the international economic and racial problems of to-day may not satisfy some national claims, it would in any event make the civilized world understand whether or no national passions had been aroused in a just cause. Instead of waiting for war and at the end of hostilities inquiring into the causes which led to it, and adjusting the consequences in the bitterness of spirit which must then prevail, let us urge that every opportunity should be taken to promote full and frank inquiries into economic or other restrictions or grievances, so that a certain amount of attention may be diverted from preparation for offence or defence in war to the discovery of the conditions of creative peace. 